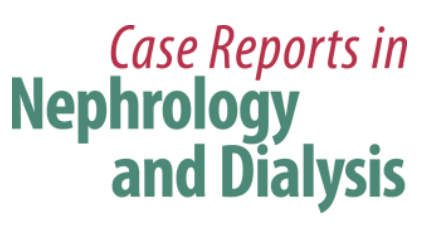

\begin{tabular}{l}
\hline Case Rep Nephrol Dial 2015;5:39-43 \\
\begin{tabular}{l|l}
\hline DOI: 10.1159/000369786 & $\begin{array}{l}\text { ○ 2014 S. Karger AG, Basel } \\
\text { 2296-9705/14/0051-0039 } \$ 39.50 / 0 \\
\text { www.karger.com/cnd }\end{array}$ \\
\hline
\end{tabular}
\end{tabular}

This is an Open Access article licensed under the terms of the Creative Commons Attribution-NonCommercial 3.0 Unported license (CC BY-NC) (www.karger.com/OAlicense), applicable to the online version of the article only. Distribution permitted for noncommercial purposes only.

\title{
A Case of Laparoscopic Ureteric Reimplantation in a Solitary Urinary System
}

\author{
Karl H. Pang ${ }^{a}$ b Saiful Miah ${ }^{b}$ Mark D. Haynes ${ }^{b}$ Neil E. Oakley ${ }^{b}$ \\ ${ }^{a}$ Academic Urology Unit, University of Sheffield, and bepartment of Urology, Royal \\ Hallamshire Hospital, Sheffield, UK
}

\section{Key Words}

Laparoscopic ureteric reimplantation · Urolithiasis · Solitary kidney

\begin{abstract}
Ureteric strictures can be caused by traumatic pelvic surgery, urolithiasis and instrumentation. There are various treatment options for ureteric stricture, including laparoscopic ureteric reimplantation. A 56-year-old female with a history of chronic left pelviureteric junction obstruction presented with urosepsis secondary to right-sided urolithiasis. The patient had a left nephrectomy and developed right-sided ureteric stricture following repeated ureteroscopy to manage her stone disease. The treatment with ureteric stenting was unsuccessful. Here we present a case on the feasibility of laparoscopic reimplantation for ureteric stricture in a solitary kidney to preserve renal function and avoid further ureteroscopy or nephrostomies.

(C) 2014 S. Karger AG, Basel
\end{abstract}

\section{Introduction}

Ureteric injuries and strictures can occur iatrogenically from pelvic surgery or result from urolithiasis, repeated ureteroscopic procedures and congenital vesicoureteric reflux. Management choices are influenced by the site, length and cause of the stricture. The available options include ureteroscopic stenting and ureteric reimplantation by open, laparoscopic or robotic approaches. Minimally invasive techniques are preferred in patients in whom open surgery is a high risk. They have been shown to be feasible, and short-term outcomes are comparable to open surgery [1]. Preserving renal function in a solitary kidney is vital, and in the current case, the patient was unsuccessfully treated with repeated ureteric stenting for a ureteric stricture. In the current report, laparoscopic reimplantation of ureter 


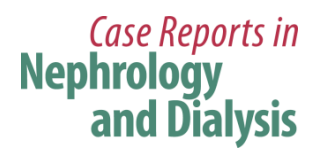

\begin{tabular}{l|l}
\hline Case Rep Nephrol Dial 2015;5:39-43 \\
\hline DOI: $10.1159 / 000369786$ & $\begin{array}{l}\text { C 2014 S. Karger AG, Basel } \\
\text { www.karger.com/cnd }\end{array}$ \\
\hline
\end{tabular}

Pang et al.: A Case of Laparoscopic Ureteric Reimplantation in a Solitary Urinary System

in a complex case of ureteric stricture secondary to urolithiasis and repeated ureteroscopy is described.

\section{Case Presentation}

Before Surgery

A 56-year-old Caucasian female who has a history of recurrent pyelonephritis, obstructive uropathy and stage 4 chronic kidney disease initially presented to the infectious disease team with bacterial endocarditis. A CT demonstrated bilateral renal obstruction: right secondary to two 4-mm distal ureteric stones, and left secondary to long-standing pelviureteric junction (fig. 1). The patient developed urosepsis, and bilateral nephrostomies were inserted to decompress the kidneys.

The patient recovered well and outpatient investigations revealed the following: (1) a 5 $\mathrm{mm}$ distal right ureteric calculus and a further 7-mm calculus more distally on repeat CT, (2) kidney split function of the left kidney 17\%, and of the right $83 \%$ on the DMSA renogram. The patient desired an improved quality of life and wanted to be free of repeated urosepsis and free of the insertion of nephrostomy. In view of this, an open left nephrectomy was performed 13 months later, following a period of haemodialysis. A nephrostogram demonstrated a right renal obstruction due to an ureteric stricture, showing inflammatory changes secondary to the patient's infected stones. Ureteroscopic laser fragmentation of the right ureteric calculi and stent insertion was performed; however, a repeat nephrostogram showed a long stricture in the lower third of the right ureter. The stent expelled spontaneously, and a new antegrade ureteric stent and nephrostomy was inserted, and a postprocedure CT confirmed a satisfactory nephrostomy and stent position; but, in addition, a persistent 7-mm right distal ureteric calculus was shown. The patient proceeded to a second ureteroscopy, stone fragmentation and stent exchange. The stent expelled again spontaneously, and an antegrade ureteric stent was reinserted. This did not last, and a third ureteroscopy and retrograde stent were inserted. The stent expelled again spontaneously, and the right kidney was found to be grossly hydronephrotic on the ultrasound scan (creatinine $476 \mu \mathrm{mol} / \mathrm{l}$, eGFR $8 \mathrm{ml} / \mathrm{min} / 1.73 \mathrm{~m}^{2}$ ), and a right nephrostomy was inserted temporarily. Another nephrostogram showed a persistent 4-cm-long stricture within the distal right ureter (fig. 2). In view of her chronic ureteric stricture and repeated spontaneous passing of stents, laparoscopic right ureteric reimplantation into the bladder dome was performed on her single urinary tract system.

\section{Procedure}

Routine pre-operative assessment and optimisation was employed with no specific mechanical bowel preparation. Three $12-\mathrm{mm}$ laparoscopic ports were inserted. The ascending colon was mobilised, the right ureter was identified and dissected off of iliac vessels to scar tissue. The bladder was mobilised, the umbilical artery obliterated and the superior vesical pedicle clipped. The bladder was hitched to the psoas muscle, opened, and the ureter spatulated. A 12-Fr probe was used to test ureteric patency. Anastomosis was performed with 3-0 vicryl continuous sutures over a 26-cm 6-Fr stent. The operative period was an uneventful procedure in which no unexpected difficulties were encountered.

\section{After Surgery}

The patient made an uncomplicated recovery and was discharged on day 2 . A postoperative cystogram performed on day 7 revealed no vesical leak. Her ureteric stent passed 


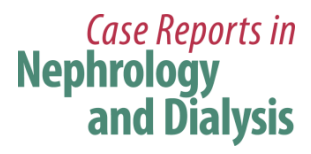

\begin{tabular}{l|l}
\hline Case Rep Nephrol Dial 2015;5:39-43 \\
\hline DOI: $10.1159 / 000369786$ & $\begin{array}{l}\text { C 2014 S. Karger AG, Basel } \\
\text { www.karger.com/cnd }\end{array}$ \\
\hline
\end{tabular}

Pang et al.: A Case of Laparoscopic Ureteric Reimplantation in a Solitary Urinary System

spontaneously prior to elective flexible-cystoscopic removal. The patient's creatinine remained stable, a nephrostogram (fig. 3) performed at 6 weeks revealed free urine flow into the bladder, and the nephrostomy was subsequently removed. Sixteen months postoperatively, the patient is well, nephrostomy-free, and her renal function has improved with a creatinine of $291 \mu \mathrm{mol} / \mathrm{l}\left(\mathrm{eGFR}=14 \mathrm{ml} / \mathrm{min} / 1.73 \mathrm{~m}^{2}\right)$.

\section{Discussion}

Long strictures are preferably managed by ureteric reimplantation. Open surgery is often associated with long hospital stays and convalescence. Laparoscopic ureteric reimplantation was initially performed on animal models for vesicoureteric reflux in 1993 [2] and was introduced in humans in 1994 shortly after [3]. Since then, refinements, including laparoscopic Boari flap procedures, have been described to enable the repair of more complex distal ureteric strictures [4]. Several series have demonstrated good success rates of up to $96 \%$ following laparoscopic surgery (no symptoms, renal deterioration, radiological evidence of residual obstruction, or need for subsequent procedures) [5-7]. Rassweiler et al. [1] performed a retrospective comparison of laparoscopic $(n=10)$ and open $(n=10)$ techniques and concluded that the laparoscopic approach is feasible, provides comparable functional outcomes, but offers the advantages of less post-operative analgesic requirement, shorter hospital stays and convalescence.

The patient in the current case developed ureteric stricture in a solitary kidney secondary to repeated instrumentation. Preserving renal function in a single system is vital. The patient had repeated stent insertion; however, these expelled spontaneously on a number of occasions, and no clear causes were identified. In patients who experience repeated spontaneous passing of stents, titanium-nickel Memokath stents can be offered [8]; however, these are not permanent and may occlude, and multiple further procedures are likely to be required in the future. Laparoscopic reimplantation offers treatment of the stricture and avoidance of stent complications and the need for further ureteroscopy or nephrostomies.

\section{Conclusion}

There are various treatment options for ureteric strictures. However, when endoscopic procedures fail, ureteric reimplantation is an option. The current report presents a successful case of laparoscopic ureteric reimplantation in a solitary kidney to preserve renal function and to avoid repeated endoscopic procedures and nephrostomies.

\section{Disclosure Statement}

The authors declare no conflicts of interest.

\section{References}

1 Rassweiler JJ, Gözen AS, Erdogru T, Sugiono M, Teber D: Ureteric re-implantation for management of ureteric strictures: a retrospective comparison of laparoscopic and open techniques. Eur Urol 2007;51:512522. 


\begin{tabular}{l|l}
\hline Case Rep Nephrol Dial 2015;5:39-43 \\
\hline DOI: 10.1159/000369786 & $\begin{array}{l}\text { ○ 2014 S. Karger AG, Basel } \\
\text { www.karger.com/cnd }\end{array}$ \\
\hline
\end{tabular}

Pang et al.: A Case of Laparoscopic Ureteric Reimplantation in a Solitary Urinary System

-2 Atala A, Kavoussi LR, Goldstein DS, Retik AB, Peters CA: Laparoscopic correction of vesicoureteral reflux. J Urol 1993;150:748.

-3 Reddy PK, Evans RM: Laparoscopic ureteroneocystostomy. J Urol 1994;152:2057.

4 Fugita OE, Dinlenc C, Kavoussi LR: The laparoscopic Boari flap. J Urol 2001;166:51.

5 Seideman CA, Huckabay C, Smith KD, Permpongkosol S, Nadjafi-Semnani M, Lee BR, Richstone L, Kavoussi LR: Laparoscopic ureteric re-implantation: technique and outcomes. J Urol 2009;181:1742-1746.

-6 Symons S, Kurien A, Desai M: Laparoscopic ureteric re-implantation: a single center experience and literature review. J Endourol 2009;23:269-274.

7 Ogan K, Abbott JT, Wilmot C, Pattaras JG: Laparoscopic ureteric reimplant for distal ureteric strictures. JSLS 2008;12:13-17.

8 Azizi A, Pasticier G, Bénard A, Lapouge 0, Ferrière JM, Ballanger P, Robert G: Tolerance and effectiveness of Memokath ${ }^{\circledR} 051$ ureteric stents: a prospective 3 year follow-up study. Prog Urol 2012;22:266-272.

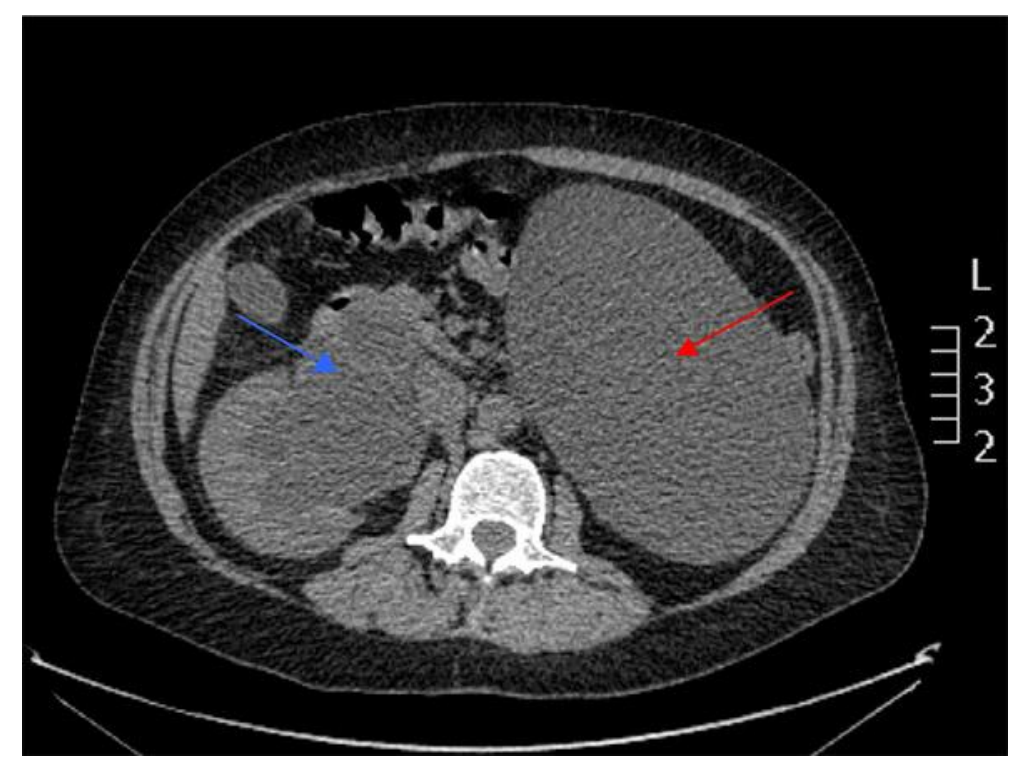

Fig. 1. A CT demonstrated right-sided hydronephrosis (blue arrow) and chronic left-sided pelviureteric junction obstruction as well as renal cyst (red arrow). 
Case Reports in

Nephrology

and Dialysis
Case Rep Nephrol Dial 2015;5:39-43

DOI: $10.1159 / 000369786$

Pang et al: A Case of Laparoscopic Ureteric Reimplantation in a Solitary Urinary System

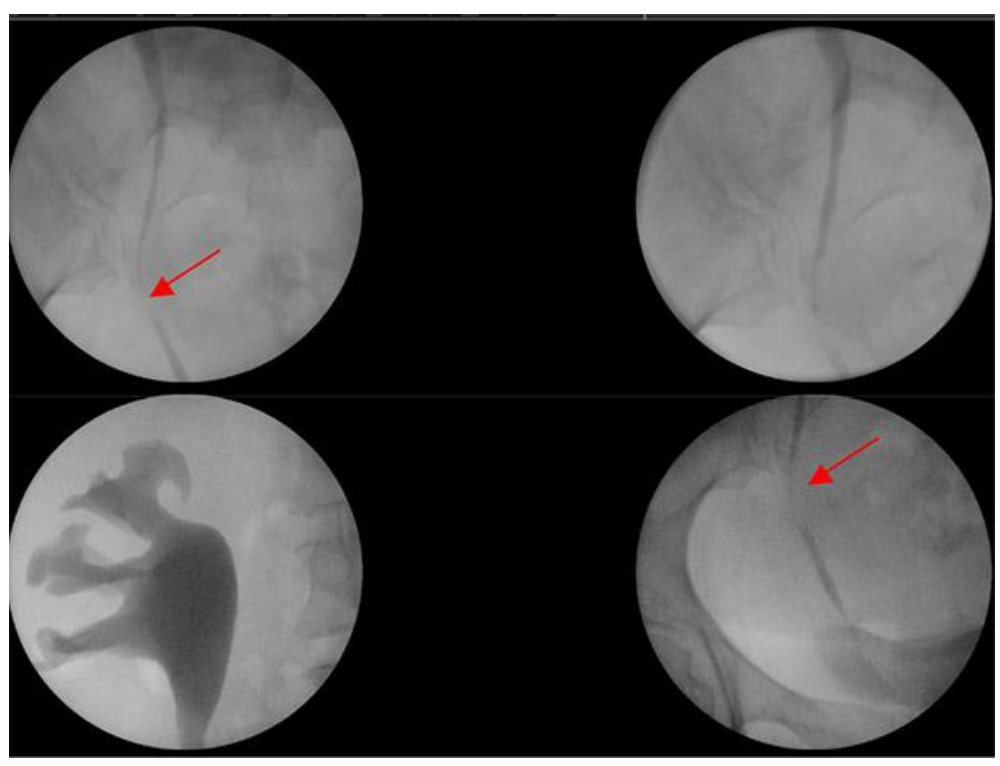

Fig. 2. Right nephrostogram demonstrated a persistent right ureteric stricture (red arrows).

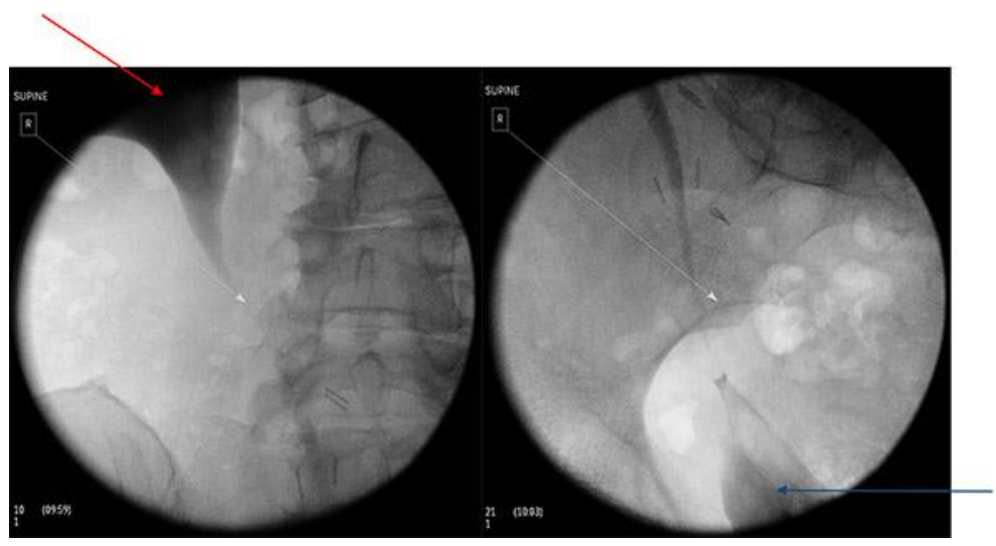

Fig. 3. A right nephrostogram performed 6 weeks after surgery showed a free flow of urine from the kidney (red arrow) to the bladder (blue arrow). 